\title{
In Unions We Trust! Analysing Confidence in Unions across Europe
}

\author{
Lorenzo Frangi, Sebastian Koos \\ and Sinisa Hadziabdic
}

\begin{abstract}
Public institutions and trade unions in particular are often portrayed as facing a deep crisis. In order to better understand to what extent unions are still perceived as legitimate institutions from the society as a whole (working and non-working individuals), we analyse the determinants of confidence in unions across 14 European countries between 1981 and 2009. Confidence in unions is explained through individual-level variables (by a rational and an ideational mechanism) and contextual-level factors (relevant economic and employment relations characteristics). Using data from the European Values Study (EVS) merged with contextual datasets, we develop a series of regression models to examine the main determinants of confidence in unions. We demonstrate that confidence in unions cannot only be traced back to the support from members and left-wing oriented individuals but it is also related to non-working individuals and vulnerable social groups, in particular when confronted with economic shocks. Our findings challenge both the 'crisis of confidence' in institutions and the 'crisis of unionism' narratives. Implications for union representation and organizing strategies are discussed.
\end{abstract}

Confidence (...) is one of the most important synthetic forces within society (Simmel 1950 [1906]: 318).

\section{Introduction}

Since the beginning of the 1980s, unions have been facing an increasingly deep crisis (Hyman 2002; Turner et al. 2001; Wallerstein and Western 2000). Union density has declined across Western Europe. The decline has been very pronounced in Anglo-Saxon countries, but is also evident in Continental and 
Southern Europe (Bryson et al. 2011; Ebbinghaus et al. 2011; Schmitt and Mitukiewicz 2012) and even the 'Ghent' countries have not been exempted (Böckerman and Uusitalo 2006). It is thus maintained that there is no evidence on whether a recovery from the crisis of unionism or the maintenance of the status quo of trade unions will be witnessed in the future (Avdagic and Baccaro 2016: 715). While being a crucial institution in empowering employees during the Fordist era, unions seem to have progressively lost their legitimacy and ultimately their raison d'etre in European societies.

Yet, the social legitimacy of unions cannot be exclusively derived from membership decline (Sullivan 2010), for two main reasons. First, the current global economic context increasingly constrains employees in joining unions, especially those experiencing more precarious and vulnerable employment conditions (Bryson and Gomez 2005; Gumbrell-McCormick 2011). Labour market dualization has significantly constrained union representation of labour market outsiders in many countries (Häusermann and Schwander 2012). However, these evolutions might not have had the same impact on the attitudinal support and confidence granted to unions. Second, even though union membership is in general limited to employees, union social legitimacy depends on the society as a whole. This is especially true in Europe where unions have played an important sociopolitical role also beyond the workplace (Gumbrell-McCormick and Hyman 2013; Hyman 2001).

The underpinnings of an institution's social legitimacy have hence a wide societal scope (Lipset and Schneider 1987). Confidence in institutions in Western countries has been declining since the 1970s and is still waning, citizens' distrust and cynicism prevail (Newton and Norris 2000; Twenge et al. 2014). The crisis of confidence in institutions seems irreversible. However, confidence in trade unions seems to have followed a different trend when compared to other institutions (Listhaug and Wiberg 1995; Smith 2012).

While there is abundant research on union membership both from a comparative and a longitudinal perspective (see Schnabel 2013), only few studies have analysed the differences in attitudinal support for unions across countries (e.g. Turner and D'Art 2012) or over time (e.g. Culpepper and Regan 2014). Therefore, in this study we analyse whether the confidence in unions in Europe follows the same patterns and trends as both the crises of confidence and crisis of unionism debates suggest. How can confidence in trade unions be explained across 14 European countries from 1981 to 2009? Do we observe a clear homogeneous trend or are there country-specific evolutions? In addition, to what extent do the drivers of confidence in unions differ from those responsible for the decline in union membership?

Our study contributes to the debates on the crisis of unionism and on the crisis of confidence in three ways. First, by studying confidence in unions we go beyond the narrow analysis of union density trends to shed light on unions' social legitimacy (e.g. Freeman et al. 2007; Gumbrell-McCormick and Hyman 2013). Second, by examining the society as a whole, we overcome the traditional limited focus on union members and/or employees in existing industrial relations studies of public opinion (e.g. Cregan 2005; D'Art and 
Turner 2008; Freeman 2007; Lipset and Meltz 2004). Finally, by studying individual and contextual determinants of confidence in unions over a 30 -year period we contribute to explaining the foundation of unions' social legitimacy, going beyond the public opinion research which focuses mostly on individual determinants in a specific moment in time (e.g. Givan and Hipp 2012). The remaining of the paper is structured as follows. In the second section, we present the theoretical approach, followed by the description of our data and methods. Section four presents the main results of the regression analysis. Finally, we discuss the main contributions of the paper and the possible implications for union representation and organizing strategies. Our findings challenge both the crisis of confidence in institutions and the crisis of unionism narratives.

\section{Explaining confidence in unions}

Confidence refers to an individual belief based on the evaluation of institutional goals and performance in fulfilling them (Luhmann 1988; Metlay 1999). ${ }^{1}$ These individual beliefs make up a reservoir of social support and institutional legitimacy, which, however varies across time (Price and Romantan 2004). Such fluctuations are related to institutional characteristics, their performance and other contextual changes independent of institutions (Price and Romantan 2004). Therefore, in line with research on confidence in institutions (Knack and Keefer 1997; Misztal 2013; Uslaner 2003; Wang and Gordon 2011) and union membership analyses (e.g. Ebbinghaus et al. 2011; Scheuer 2011; Snape and Redman 2004), both individual and countryspecific characteristics are considered as fundamental drivers in determining the expression of confidence towards unions.

\section{Individual-Level Determinants}

In the debates on institutional trust and union support, two main explanations can be identified: a rational and an ideational mechanism. According to the rational mechanism, the expression of trust is essentially driven by a cost-benefit analysis. Such an analysis can be developed along two different types of considerations: unions 'can do' and unions 'will do' (Colquitt et al. 2007). In the former case, the expression of trust in unions is mainly the result of a track record of institutional performance and tangible personal benefits received from unions in the past. In the latter case, confidence in unions is centrally based on a future-oriented expectation of what unions 'will $d o$ '. People evaluate the possibility that unions will perform actions that may positively affect their personal welfare. The expression of confidence is therefore linked to a perception of unions as a trustworthy institution, their perceived integrity and fiduciary responsibilities, as well as on union competence in achieving institutional goals (Barber 1983; Mayer et al. 1995). This expression of confidence thus implies a 'leap of faith' about the future institutional performance (Sapsford and Abbott 2006: 61). 
As it has been shown by research about employment advantages and empowerment provided by unions (e.g. Bennett and Kaufman 2007), we expect that unions ' $c a n d o$ ' considerations concern primarily people who are directly affected by their actions, leading them to be more confident in unions (Givan and Hipp 2012). More specifically, we expect that union members have a higher probability to express confidence in unions than non-members (hypothesis 1a).

In the general debate about the crisis of confidence in social institutions, vulnerable social groups have been portrayed as the most pessimistic and cynical. Either linked to individual characteristics (such as level of income, education, age, gender and ethnic origin) or the type of employment contract (Burgess et al. 2013: 4084-5), social vulnerability pushes citizens to develop a feeling of being excluded from the social system and, in response, they are less likely to trust institutions (Farnsworth 2003). More specifically, the debate about confidence in social institutions demonstrated how confidence wanes when citizens are struggling economically (Greenfield 2009), have achieved only low educational levels, belong to minorities or younger generations (e.g. Schwadel and Stout 2012; Twenge et al. 2014). This evidence is in line with core findings about union membership determinants. Indeed, being a woman (Ebbinghaus et al. 2011; Kirmanoğlu and Başlevent 2012), younger or rather old (Blanchflower and Oswald 2008), foreign-born (Lee 2005; McGovern 2007; Turner et al. 2008) and subject to more precarious employment arrangements (Ebbinghaus et al. 2011) diminish the probability of being a union member. Also, household income partially lost its historical primary significance in determining union membership, since more and more union members have secure jobs and revenues, such as white collars in the public sector (Schnabel 2013). By contrast, studies on attitudes towards unions found that such vulnerable conditions are either non-relevant (D'Art and Turner 2008; Goslinga and Sverke 2003) or can have positive effects (Bronfenbrenner and Hickey 2004; Freeman and Rogers 2006). Smith (2012) studying the US case, underlines that the relationship between vulnerability and confidence in unions appears inverted since more vulnerable groups express higher confidence in unions. This sentiment might be much stronger in Europe where unions have also played a more vibrant role beyond the workplaces. Indeed, unions in Europe have been a social institution capable of acting as a 'sword of justice' (Flanders 1975), committed to the promotion of social policies aimed at protecting vulnerable social groups (Hyman and Gumbrell-McCormick 2010; Streeck and Hassel 2003). Furthermore, in the last decades, unions are increasingly present in the media to promote this image to which vulnerable individuals can be particularly sensitive (Baccaro et al. 2003). We therefore expect that individuals with vulnerable profiles have higher chances of being confident in unions, hoping for an improvement of their conditions through unions' actions (hypothesis 1b).

Confidence in unions can also derive from an ideational mechanism. Here, the expression of confidence in an institution is based on the perception of shared values between who expresses confidence and the possible recipient 
of this confidence (Cvetkovich and Earle 1995). The degree of alignment perceived by individuals between their own values and core union goals are fundamental in structuring individual feelings of union legitimacy. Unions' institutional role in promoting justice in the relationship between labour and capital touches people's political sensitivity along the most important cleavage in the political arena; liberal versus conservative stances (e.g. Gabel and Hix 2002). Central relevance of people's ideational inclination, along with their political interest and engagement, has been found in both the few studies of confidence in unions (Smith 2012) as well as in the number of studies explaining the union membership choice (Checchi et al. 2010; Frangi and Barisione 2015; Scheuer 2011; Snape and Redman 2004). Therefore, we expect that the greater the extent to which people identify with ideational positions that lean towards the left, are interested and actively engaged in politics, the more likely they are to trust unions (hypothesis 2).

These two mechanisms, rational and ideational, might also interact in their influence on the expression of confidence in unions. According to Weber (1958: 280), 'Not ideas, but material and ideal interests, directly govern men's conduct. Yet very frequently the "world images" that have been created by "ideas" have, like switchmen, determined the tracks along which action has been pushed by the dynamic of interest'. This can be more pronounced when unions are facing several constraints in providing economic advantages (Brym et al. 2013; Rosenfeld 2014). In line with this argument, we would expect that certain ideational dispositions, a leftist political orientation in particular, might offset the rational mechanism that is closely related to one's socioeconomic position in granting confidence to unions. Thus, people belonging to high socioeconomic positions, who can be expected to have no rational reasons to trust unions, might well do so if they hold leftist political ideals. On the other hand, people in lower social layers might have a strong rational interest in unions, independently of their political inclination. Therefore, political ideals should play a more important role in explaining confidence in unions when people's material interest in unions is weak (hypothesis 3).

\section{Contextual-Level Determinants}

Confidence in an institution is also shaped by contextual factors. While, to our knowledge, there is no specific research targeted to confidence in unions that considered the influence of contextual factors, positive economic conditions have been portrayed as a fertile environment to raise the legitimacy of social institutions, whereas negative economic conditions, recessions in particular, weaken confidence in institutions (Guiso et al. 2006; Knack and Keefer 1997: 1251; Zak and Knack 2001). This is especially true for the ones playing a pivotal role in the economic arena, such as unions. While positive economic conditions might raise institutional legitimacy, negative economic events have been found to be much more important in substantially undermining confidence in institutions (Greenfield 2009; King and Karabell 2003). Similar 
results have been found in the debate about union membership since better economic conditions support higher union density, whereas recessions and higher unemployment undercut union density (Checchi and Visser 2005; Schnabel 2013). We therefore expect that confidence in unions is higher in countries facing positive economic conditions (hypothesis 4).

While economic conditions might influence the confidence towards institutions, institutional characteristics have also a primary relevance. Granting confidence is influenced by the institution's actions, effectiveness, and performance cumulated through time in a specific society (Newton and Norris 2000; Rothstein and Stolle 2008; Yamagishi 2003). This engenders cultural norms, traditions and expectations reflected in different levels of confidence in different societies (Smith 2012). In the case of trade unions, the debate about the variety of employment relations regimes has delineated important features of trade unions in different countries and their relevance in determining union density (Crouch 1985; Gumbrell-McCormick and Hyman 2013; Kenworthy 2001). Effectiveness and performance of trade unions is centrally represented by their ability to influence the relationship between labour and capital through collective bargaining and political pressure on government to protect employees (Schmitter and Streeck 1981). Extant studies have shown the crucial importance of institutions in explaining levels and trend of union density (Brady 2007; Ebbinghaus and Visser 1999; Western 1994). Conversely, in one of the few comparative studies on attitudes towards unions, D'Art and Turner (2008) find only weak support for an institutional effect on the employees' demand for strong unions across Europe. Since they only use a rough institutional proxy based on the Varieties of Capitalism clustering and union density of countries to explain a specific attitude, we argue more research is needed to analyse the impact of institutions on public opinion towards unions. We thus expect that people living in countries with a higher level of bargaining coordination and higher employment protection are more likely to consider trade unions as more effective and powerful institutions and hence be more prone to trust them (hypothesis 5).

\section{Data and methodology}

\section{Data}

In order to test our hypotheses, we use the data of the European Values Study (EVS). The EVS is the only available survey that consistently includes a question about confidence in unions across several European countries since the beginning of the 'crisis of unionism'. ${ }^{2}$ The EVS uses a multistage or stratified random sample of the adult population (older than 18) in each country, regardless of respondents' citizenship. Overall response rates are rather high and representativity according to gender, education and age composition of each country is warranted. Moreover, major efforts have been made to include immigrant populations in the representative sample. ${ }^{3}$ After data cleaning, information on 42,326 respondents from 14 countries (Austria, 
Belgium, Denmark, Finland, France, Germany, Ireland, Italy, Netherlands, Norway, Portugal, Spain, Sweden, United Kingdom) and four waves (19811982, 1991, 1999-2000, 2008-2009) remain for analysis. The final dataset in unbalanced since not all countries were surveyed in all four waves.

Despite its richness, not all waves of the EVS provide all the variables that are necessary to adequately test all of our hypotheses. In order to overcome this limitation, as described below, two of our regression models are based only on data of the fourth wave, which provides the richest set of variables for our analyses.

In the EVS, respondents were presented a show card with different organizations and were asked the following standard question: 'I am going to name a number of organizations. For each one, could you tell me how much confidence you have in them: is it a great deal (1) quite a lot (2) not very much (3) or none at all (4)?'. We focus on the answers about 'labour unions'. In order to simplify the interpretation of the results, we recoded the variable into a dichotomous outcome ( 0 for the answer options 'None at all' and 'Not very much' and 1 for 'Quite a lot' and 'A great deal'). Descriptive statistics of this variable are available in Table A1.

At the individual level, the following variables, available in all four waves, have been included in all of our models: a set of dummies for every wave, union membership status ('Non-member' and 'Member'), gender, age ('030 ', '31-50' and '51 years or more'), household income ('Low', 'Medium' and 'High' based on country specific household income, the three categories originally available in the EVS representing equally large groups within each country), the employment status ('Employee', either 'Full-time' or 'Parttime'; 'Self-employed'; and 'Non-working', that is 'Unemployed', 'Retired', 'Housewife', 'Student' or 'Other' $\left.{ }^{4}\right)$, a political orientation variable considered as continuous (expressed on a 1-10 scale, 1 representing 'Extreme left' and 10 'Extreme right'), a variable operationalizing the level of political interest of an individual (on a scale from 0 'Not at all interested' to 3 'Very interested') and a variable operationalizing the level of political activism (ranging from 0 to 3 , the variable has been obtained as an additive scale from three questions inquiring whether the respondent has signed a petition, participated in a demonstration and/or in a boycott).

Because of the unavailability of some variables of interest in the first three waves, we include in the second and third model three variables available in the fourth wave of the EVS and representing better operationalizations for some of our hypotheses. These are the highest level of education attained (recoded in 'Less than secondary level', 'Secondary level' and 'Tertiary level'), the socioeconomic position given by one of the nine categories of the European Socioeconomic classification ('Large employers, higher managers and professionals', 'Lower managers, professionals and supervisors', 'Intermediate occupations', 'Small employers and self-employed', 'Small employers and self-employed in agriculture', 'Lower supervisors and technicians', 'Lower sales and service', 'Lower technicians' and 'Routine jobs'), and a dummy variable operationalizing the 
migration status ('Born in the country' and 'Born outside the country'). Summary statistics on all these variables are available in Table A2.

We complete the information available in the EVS by merging it at the country level with some datasets including relevant contextual-level variables. The economic conditions of a country are measured through the GDP per capita in current US\$ (divided by thousand and by taking its natural logarithm to account for its skewed nature) and the unemployment rate, both obtained from the IMF database. Bargaining coordination is represented by an indicator proposed by Kenworthy (2001: 78) measuring the degree of coordination of wage-setting (recoded in three categories by considering the original category 1 as 'Weak', 2 and 3 as 'Moderate' and 4 and 5 as 'Strong') and available in the ICTWSS database. Finally, the level of employment protection for regular and temporary workers is measured by the EPR_V1 (measuring the strictness of regulation of individual dismissal of employees on regular/indefinite contracts) and EPT_V1 (measuring the strictness of regulation on the use of fixed-term and temporary work agency contracts) indicators available in the OECD/IDB Employment Protection Database. Additionally, in order to compute some descriptive statistics used in section 4.1, we also employed the data about union density available in the ICTWSS database and the data about the total population and the number of people in employment from the IMF database. Descriptive statistics of these indicators are available in Table A3.

\section{Model Specification}

In order to examine our hypotheses, we rely on a linear probability model (LPM) approach by applying OLS to regression models including our binary confidence in unions variable as outcome and a series of individual, contextual and interaction term variables as independent factors. In order to obtain correct test statistics, we use bootstrap standard errors with 50 replications. Four main reasons motivate the use of such approach instead of the usual logit or probit specifications used with binary outcomes. First, for all our independent variables, our main interest lies in the estimation of average marginal effects and it has been shown that, provided the number of observations is sufficiently large to be able to rely on the asymptotic behaviour of OLS (as it is in our case), the LPM approach provides a consistent estimation of such effects (Angrist and Pischke 2009; Wooldridge 2010: chapter 15). On a second level, non-linear models such as logit or probit suffer from a certain number of rather underestimated limitations related to the fact that the estimates they provide are highly dependent on the amount of residual variance in a model (Mood 2010; Wooldridge 2010: chapter 15). In particular, such issues hinder the conversion of the original estimates into average marginal effects and limits the possibility to compare nested models and models estimated on different sub-samples of the same population (as it is implicitly done by including an interaction term). Third, using OLS has the great advantage of freeing us of any distributional assumptions to make 
about the form of the error term (Wooldridge 2010: chapter 15). Relying on the asymptotic behaviour of OLS and using robust standard errors to obtain correct test statistics (such as the bootstrap standard errors we use), we can get consistent and unbiased estimates for every type of distribution of the error term. And last but not least, the estimates one gets through a LPM already represent the desired average marginal effects and can be interpreted as the additive probability effect of observing the event coded as 1 in the dependent variable, that is declaring to be confident in unions in our case (Angrist and Pischke 2009; Wooldridge 2010: chapter 15).

\section{Results}

\section{Descriptive Results}

In Figure 1, we trace the average percentage change of confidence in unions and union density using the year of the first wave $(1981=0)$ as reference point. We restrict our attention to the 10 countries consistently surveyed across all four waves. The two averages have been computed as weighted averages in order to account for the differences in terms of size between countries. For confidence in unions, we weighted the contribution of each country by its population in each one of the four waves. For union density, the contributions

FIGURE 1

Variations in Confidence in Unions and Union Density $(1981=0)$.

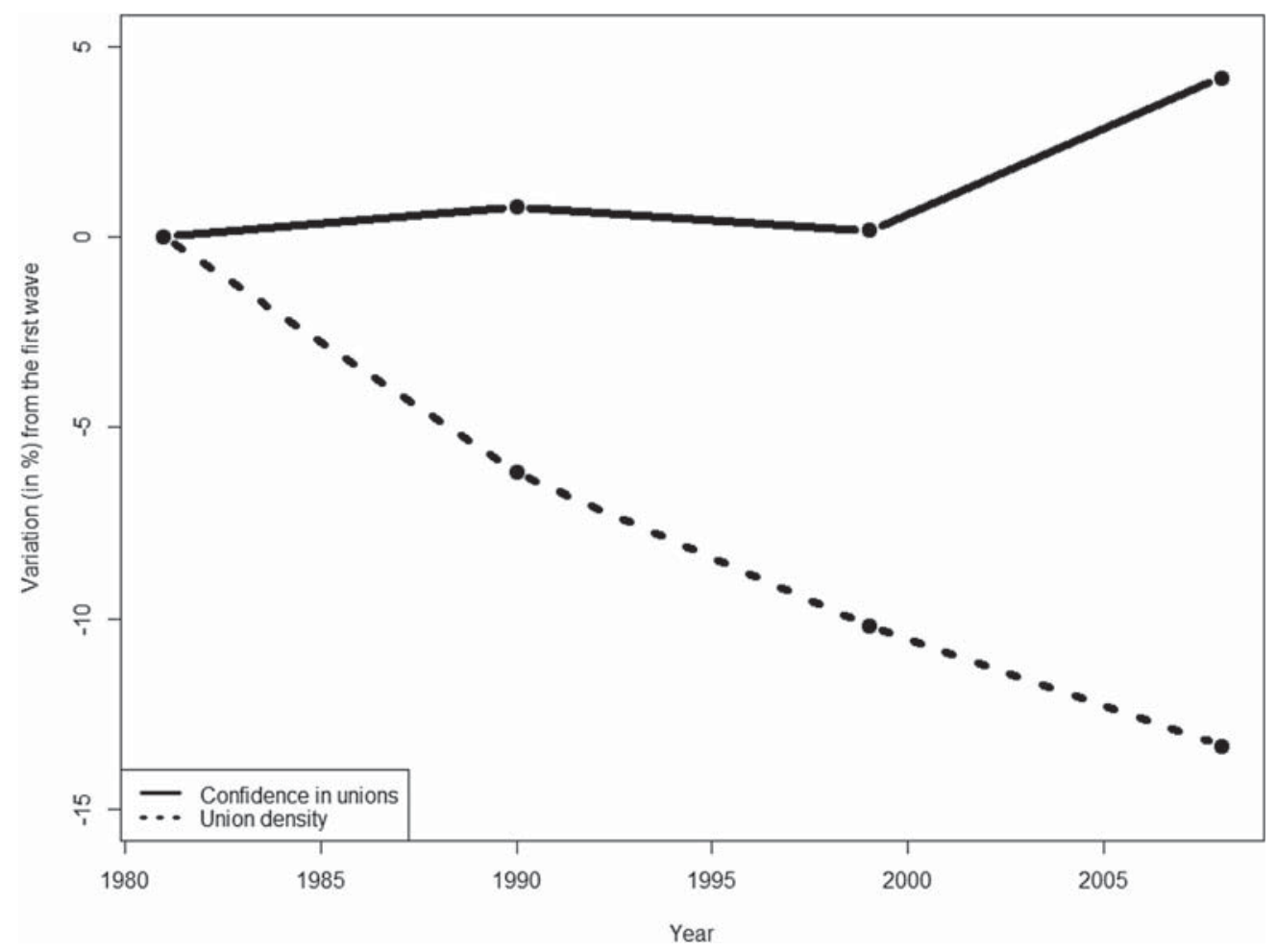

Note: Data only contains Belgium, Denmark, France, Germany, Ireland, Italy, the Netherlands, Spain, Sweden and the United Kingdom. 
TABLE 1

Confidence in Unions Per Country and Wave

\begin{tabular}{lcccccc}
\hline & \multicolumn{5}{c}{ Confidence in unions } & \multirow{2}{*}{ Confidence in unions } \\
\cline { 2 - 5 } Country & $1981-1982$ & 1990 & $1999-2000$ & 2008-2009 & $\begin{array}{c}\text { Overall } \\
\text { difference }\end{array}$ & Average\% \\
\hline Austria & - & 34.2 & 32.2 & 29.0 & $\mathbf{- 5 . 2}$ & 31.8 \\
Belgium & 32.7 & 36.6 & 36.7 & 47.3 & 14.6 & 38.3 \\
Denmark & 51.3 & 46.8 & 48.0 & 58.7 & 7.4 & 51.2 \\
Finland & - & 31.4 & 54.6 & 45.3 & 13.9 & 43.8 \\
France & 38.7 & 32.1 & 34.7 & 42.8 & 4.1 & 37.1 \\
Germany & 36.0 & 33.9 & 37.9 & 37.6 & 1.6 & 36.3 \\
Ireland & 37.5 & 42.8 & 46.0 & 61.3 & 23.8 & 46.9 \\
Italy & 27.3 & 34.2 & 28.9 & 30.0 & 30.1 & 2.7 \\
Netherlands & 38.8 & 54.3 & 57.2 & 52.0 & 13.2 & 50.6 \\
Norway & 55.3 & 59.1 & - & 64.2 & 8.9 & 59.6 \\
Portugal & - & 28.6 & 47.7 & 44.8 & 16.2 & 40.4 \\
Spain & 32.6 & 39.4 & 26.5 & 38.1 & 5.5 & 34.2 \\
Sweden & 50.3 & 40.9 & 42.1 & 37.0 & $-\mathbf{1 3 . 3}$ & 42.6 \\
United Kingdom & 26.3 & 25.3 & 25.9 & 30.6 & 4.3 & 27.0 \\
Total & 38.9 & 38.6 & 40.0 & 44.2 & 5.3 & 40.7 \\
\hline
\end{tabular}

of each country are weighted by the number of people in employment in each country since union membership concerns mainly this category of individuals.

Figure 1 shows a very interesting divergence between the two indicators. While union density drops almost linearly, the percentage of people declaring to have confidence in unions remains relatively stable during the first three waves and importantly increases (around 4 per cent) between 1999 and 2008. The crisis of unions in terms of union density is hence not associated with a crisis in terms of the level of trust society grants them.

However, this overall trend of confidence in unions could by biased by the trends taking place in large countries, receiving the highest weights when computing the average.

We hence also provide an analysis for every individual country. Table 1 presents the mean level of confidence in unions by country and wave (column 1-4) and traces the overall difference in percentage between the first available and the final wave (column 5). While some countries show a stronger increase than others, overall, we see that 12 out of 14 countries show an increasing trend in terms of the level of confidence in unions through time. Interpreting the precise reasons behind each national longitudinal variation goes beyond the objectives of this paper, but in the next section, we will provide some explanations about why we observe an overall positive trend. It is however interesting to at least remark that unions in the only two countries showing a negative trend, Sweden and, to a much lesser extent, Austria, have been facing discrediting issues (Habbard 2008; Kunkel and Pontusson 1998; Traxler and Pernicka 2007). We contextualize these issues as part of a larger picture in the discussion section. 


\section{Regression Results}

We now turn to a series of linear probability models with the goal of testing our hypotheses and shedding some light on the variability across countries and time. Two sets of models are provided. The first three models (Table 2) focus solely on individual-level variables. While the first is based on variables consistently available across all waves, the second and third are confined to the fourth wave, using three additional variables only available in this wave. The second group of models (Table 3 ) adds contextual-level determinants to the variables of the first model. In the fourth model, we start by including a set of country dummies, in the fifth we add the two variables operationalizing economic conditions, in the sixth the level of bargaining coordination and in the seventh we join the two variables measuring the level of employment protection for regular and temporary workers. Finally, in the last model, we examine the interaction between unemployment and waves.

Focusing on model 1, we first see that the wave dummies confirm the general trend we described in the previous section. While there is no significant difference between the first and second wave, we observe a significant increase in the level of confidence in unions in the third wave ( 2 per cent) and an even more significant and relevant increase in the fourth wave (6 per cent).

The union membership variable shows that union members have a higher probability ( 23 per cent) to be confident in unions than non-members. This is in line with hypothesis 1a and with the results outlined in previous research (e.g. Givan and Hipp 2012; Heshizer 1985; Kochan 1979). Looking at how gender affects our outcome variable, we see that women, generally occupying more vulnerable positions in the labour market, have a significantly higher propensity to trust unions in comparison to men, even though the magnitude of the difference is quite small (1 per cent). The effect is in line with our hypothesis $1 \mathrm{~b}$. Moreover, the effect by age follows the expected direction. Individuals aged 30 or less, usually having a more precarious job condition than older ones, are those with the highest propensity to declare confidence in unions. We see that the level of confidence decreases for middle-aged individuals and then partially recovers for people older than 50. Observing how confidence varies across household income categories, we see that, again in line with hypothesis $1 \mathrm{~b}$, the higher the income, the lower is the probability for the respondent to trust unions. In other words, economically vulnerable individuals have a higher propensity to trust unions. The variations we observe by employment status follow again what we expect according to hypothesis $1 \mathrm{~b}$ since part-time workers have a significantly higher propensity to trust unions ( 2 per cent) than full-time workers, whereas self-employed respondents show an effect (5 per cent) in the opposite direction. Interestingly, non-working individuals are the category showing the highest propensity to be confident in unions ( 3 per cent more than full-time workers). This shows that unions are capable of exerting an important influence even on those individuals not directly affected by their actions, in line with their increased involvement in the public sphere (Baccaro et al. 2003). 
TABLE 2

Individual-Level Models

\begin{tabular}{|c|c|c|c|}
\hline Variables & Model 1 & Model 2 & Model 3 \\
\hline \multicolumn{4}{|l|}{ Wave (Ref.: Wave 1) } \\
\hline Wave 2 & 0.0023 & & \\
\hline Wave 3 & $0.0222^{* *}$ & & \\
\hline Wave 4 & $0.0570^{* * *}$ & & \\
\hline Union membership (Ref.: Non-member) & $0.228^{* * *}$ & $0.246^{* * *}$ & $0.246^{* * *}$ \\
\hline Sex (Ref.: Man) & $0.00988^{*}$ & $0.0241^{* *}$ & $0.0199^{*}$ \\
\hline \multicolumn{4}{|l|}{ Age (Ref.: $0-30)$} \\
\hline $31-50$ & $-0.0493^{* * *}$ & $-0.0927^{* * *}$ & $-0.0929^{* * *}$ \\
\hline 51 or more & $-0.0457^{* * *}$ & $-0.124^{* * *}$ & $-0.126^{* * *}$ \\
\hline \multicolumn{4}{|l|}{ Household income (Ref.: Low) } \\
\hline Medium & $-0.0200^{* *}$ & -0.00151 & -0.00189 \\
\hline High & $-0.0632^{* * *}$ & -0.0104 & -0.01 \\
\hline \multicolumn{4}{|l|}{ Employment status (Ref.: Employee full-time) } \\
\hline Employee part-time & $0.0212^{*}$ & 0.011 & 0.0129 \\
\hline Self-employed & $-0.0506^{* * *}$ & -0.0276 & -0.0232 \\
\hline Non-working & $0.0293^{* * *}$ & $0.0244^{*}$ & $0.0268^{*}$ \\
\hline Political orientation & $-0.0324^{* * *}$ & $-0.0360^{* * *}$ & $-0.0144^{*}$ \\
\hline Political interest & $0.0233^{* * *}$ & $0.0300^{* * *}$ & $0.0293^{* * *}$ \\
\hline Political activism & $0.0144^{* * *}$ & $0.0337^{* * *}$ & $0.0317^{* * *}$ \\
\hline \multicolumn{4}{|l|}{ Education level (Ref.: Lower) } \\
\hline Middle & & $-0.0303^{* *}$ & $-0.0280^{*}$ \\
\hline Upper & & $-0.0510^{* *}$ & $-0.0506^{* *}$ \\
\hline \multicolumn{4}{|l|}{ Social class (Ref.: Routine occupations) } \\
\hline Large employers & & $-0.0542^{* *}$ & $0.172^{* * *}$ \\
\hline Lower managers & & $-0.0322^{*}$ & $0.0987^{*}$ \\
\hline Intermediate occupations & & -0.0146 & $0.131^{*}$ \\
\hline Small employers & & $-0.106^{* * *}$ & -0.0186 \\
\hline Small employers agric. & & -0.046 & 0.136 \\
\hline Lower supervisors and technicians & & -0.00351 & $0.129^{*}$ \\
\hline Lower sales and service & & 0.011 & 0.0553 \\
\hline Lower technical occupations & & 0.0128 & 0.0696 \\
\hline Foreign born & & $0.0451^{* * *}$ & $0.0439^{* * *}$ \\
\hline \multicolumn{4}{|l|}{ Routine occupations $\times$ pol. orient. } \\
\hline Large employers $\times$ pol. orient & & & $-0.0430^{* * *}$ \\
\hline Lower managers $\times$ pol. orient & & & $-0.0264^{* * *}$ \\
\hline Intermediate occupations $\times$ pol. orient & & & $-0.0294^{* *}$ \\
\hline Small employers $\times$ pol. orient & & & -0.0189 \\
\hline Small employers agric. $\times$ pol. orient & & & -0.0352 \\
\hline Lower supervisors and techn. $\times$ pol. orient & & & $-0.0269^{*}$ \\
\hline Lower sales and service $\times$ pol. orient & & & -0.00963 \\
\hline Lower technical occupations $\times$ pol. orient. & & & -0.0117 \\
\hline Constant & $0.506^{* * *}$ & $0.608^{* * *}$ & $0.505^{* * *}$ \\
\hline$N$ & 42,326 & 11,421 & 11,421 \\
\hline Adj. $R^{2}$ & 0.0719 & 0.0972 & 0.0994 \\
\hline$F p$-Value & 0 & 0 & 0 \\
\hline
\end{tabular}

Note: significance levels: ${ }^{*} p<0.05 .{ }^{* *} p<0.01{ }^{* * *} p<0.001$. For easier depiction standard errors are not reported. 
TABLE 3

Contextual-Level Models

\begin{tabular}{|c|c|c|c|c|c|}
\hline Variables & Model 4 & Model 5 & Model 6 & Model 7 & Model 8 \\
\hline \multicolumn{6}{|l|}{ Wave (Ref.: Wave 1) } \\
\hline Wave 2 & 0.00416 & $-0.0542^{* * *}$ & -0.0249 & -0.0206 & -0.0454 \\
\hline Wave 3 & $0.0240^{* *}$ & $-0.0542^{*}$ & -0.0234 & -0.00378 & 0.00675 \\
\hline Wave 4 & $0.0505^{* * *}$ & $-0.0714^{*}$ & -0.0126 & 0.0113 & -0.0694 \\
\hline $\begin{array}{l}\text { Union membership } \\
\text { (Ref.: Non-member) }\end{array}$ & $0.202^{* * *}$ & $0.202^{* * *}$ & $0.203^{* * *}$ & $0.203^{* * *}$ & $0.203^{* * *}$ \\
\hline Sex (Ref.: Man) & $0.00951^{*}$ & 0.00949 & $0.00964^{*}$ & 0.00983 & $0.00955^{*}$ \\
\hline \multicolumn{6}{|l|}{ Age (Ref.: 0-30) } \\
\hline $31-50$ & $-0.0511^{* * *}$ & $-0.0512^{* * *}$ & $-0.0513^{* * *}$ & $-0.0513^{* * *}$ & $-0.0516^{* * *}$ \\
\hline 51 or more & $-0.0459^{* * *}$ & $-0.0458^{* * *}$ & $-0.0462^{* * *}$ & $-0.0462^{* * *}$ & $-0.0462^{* * *}$ \\
\hline \multicolumn{6}{|l|}{$\begin{array}{l}\text { Household income } \\
\text { (Ref.: Low) }\end{array}$} \\
\hline Medium & $-0.0193^{* *}$ & $-0.0197^{* *}$ & $-0.0202^{* *}$ & $-0.0204^{* *}$ & $-0.0207^{* * *}$ \\
\hline High & $-0.0617^{* * *}$ & $-0.0617^{* * *}$ & $-0.0610^{* * *}$ & $-0.0610^{* * *}$ & $-0.0615^{* * *}$ \\
\hline \multicolumn{6}{|l|}{$\begin{array}{l}\text { Employment status } \\
\text { (Ref.: Employee } \\
\text { full-time) }\end{array}$} \\
\hline Employee part-time & $0.0182^{*}$ & 0.0177 & 0.0168 & 0.0159 & $0.0164^{*}$ \\
\hline Self-employed & $-0.0588^{* * *}$ & $-0.0578^{* * *}$ & $-0.0578^{* * *}$ & $-0.0585^{* * *}$ & $-0.0577^{* * *}$ \\
\hline Non-working & $0.0317^{* * *}$ & $0.0319^{* * *}$ & $0.0313^{* * *}$ & $0.0311^{* * *}$ & $0.0314^{* * *}$ \\
\hline Political orientation & $-0.0359^{* * *}$ & $0.0358^{* * *}$ & $-0.0357^{* * *}$ & $-0.0358^{* * *}$ & $-0.0357^{* * *}$ \\
\hline Political interest & $0.0239^{* * *}$ & $0.0239^{* * *}$ & $0.0242^{* * *}$ & $0.0245^{* * *}$ & $0.0245^{* * *}$ \\
\hline Political activism & $0.0172^{* * *}$ & $0.0175^{* * *}$ & $0.0176^{* * *}$ & $0.0176^{* * *}$ & $0.0176^{* * *}$ \\
\hline \multicolumn{6}{|l|}{ Country (Ref.: UK) } \\
\hline Austria & $0.0366^{* *}$ & $0.0343^{*}$ & -0.0208 & -0.0698 & -0.038 \\
\hline Belgium & $0.130^{* * *}$ & $0.125^{* * *}$ & $0.0834^{* *}$ & 0.0333 & 0.0528 \\
\hline Denmark & $0.143^{* * *}$ & $0.121^{* * *}$ & $0.0701^{*}$ & 0.028 & 0.0546 \\
\hline Finland & $0.166^{* * *}$ & $0.161^{* * *}$ & $0.0799^{*}$ & 0.0321 & 0.0586 \\
\hline France & $0.101^{* * *}$ & $0.0897^{* * *}$ & 0.00353 & -0.0741 & -0.0524 \\
\hline Germany & $0.0583^{* * *}$ & $0.0551^{* * *}$ & -0.00072 & -0.0701 & 0.0465 \\
\hline Ireland & $0.231^{* * *}$ & $0.238^{* * *}$ & $0.203^{* * *}$ & $0.216^{* * *}$ & $0.238^{* * *}$ \\
\hline Italy & $0.0373^{* *}$ & $0.0393^{* * *}$ & -0.0505 & $-0.147^{* * *}$ & $-0.123^{*}$ \\
\hline Netherlands & $0.219^{* * *}$ & $0.211^{* *}$ & $0.150^{* * *}$ & $0.0911^{*}$ & $0.123^{*}$ \\
\hline Norway & $0.284^{* * *}$ & $0.248^{* * *}$ & $0.193^{* * *}$ & $0.133^{* *}$ & $0.162^{* *}$ \\
\hline Portugal & $0.161^{* * *}$ & $0.220^{* * *}$ & $0.115^{*}$ & -0.039 & -0.00334 \\
\hline Spain & $0.00940^{* * *}$ & $0.108^{* * *}$ & 0.0529 & -0.055 & -0.0383 \\
\hline Sweden & $0.0840^{* * *}$ & $0.0713^{* * *}$ & 0.0282 & -0.0368 & -0.0231 \\
\hline $\ln (\mathrm{GDP} / 1,000)$ & & $0.0746^{* * *}$ & 0.0407 & 0.0442 & $0.0663^{*}$ \\
\hline Unemployment & & 0.00193 & -0.00184 & -0.0007 & 0.000423 \\
\hline \multicolumn{6}{|l|}{$\begin{array}{l}\text { Bargaining } \\
\text { coordination (ref.: } \\
\text { Weak) }\end{array}$} \\
\hline Moderate & & & $0.0944^{* *}$ & 0.0642 & 0.0296 \\
\hline Strong & & & 0.0448 & 0.0147 & -0.0164 \\
\hline Empl. prot. regular & & & & $0.0420^{* *}$ & $0.0443^{* *}$ \\
\hline Empl. prot. temporary & & & & $0.0154^{* * *}$ & $0.0183^{* * *}$ \\
\hline \multicolumn{6}{|l|}{ Wave $1 \times$} \\
\hline \multicolumn{6}{|l|}{$\begin{array}{l}\text { Unemployment } \\
\text { (Ref.) }\end{array}$} \\
\hline Wave $2 \times$ & & & & & 0.0012 \\
\hline Unemployment & & & & & \\
\hline
\end{tabular}


TABLE 3

Continued

\begin{tabular}{|c|c|c|c|c|c|}
\hline Variables & Model 4 & Model 5 & Model 6 & Model 7 & Model 8 \\
\hline Wave $3 \times$ & & & & & -0.00369 \\
\hline Unemployment & & & & & \\
\hline Wave $3 \times$ & & & & & -0.00369 \\
\hline Unemployment & & & & & \\
\hline Wave $3 \times$ & & & & & -0.00369 \\
\hline Unemployment & & & & & \\
\hline Wave $4 \times$ & & & & & $0.00755^{*}$ \\
\hline Unemployment & & & & & \\
\hline Constant & $0.412^{* * *}$ & $0.236^{* * *}$ & $0.336^{* * *}$ & $0.254^{* * *}$ & 0.188 \\
\hline$N$ & 42,326 & 42,326 & 42,326 & 42,326 & 42,326 \\
\hline Adj. $R^{2}$ & 0.095 & 0.0952 & 0.0959 & 0.0963 & 0.0967 \\
\hline$F p$-value & 0 & 0 & 0 & 0 & 0 \\
\hline
\end{tabular}

Note: Significance levels: ${ }^{*} p<0.05 .{ }^{* *} p<0.01 .^{* * *} p<0.001$. For easier depiction standard errors are not reported.

Finally, the three variables related to the ideational dimension confirm hypothesis 2 . By moving on the political orientation scale, we see that, on average, a 1-point shift to the right significantly decreases the probability of trusting unions by 3 per cent, which is in line with the results of previous research (Ebbinghaus et al. 2011; Kirmanoğlu and Başlevent 2012). A 1-point shift in the scales representing the level of interest in politics and political activism is associated with a significant increase of the propensity to be confident in unions by 2 and 1 per cent respectively.

In model 2, we see that almost all the effects described in the first model follow the same direction, even though some variations in the magnitude are noticeable. The only exceptions are the variables related to household income and employment status, where some significant effects disappear because of the overlap with the level of education and the socioeconomic status introduced in the second model. Looking at the three new variables added in the model, we see that all three effects are in line with hypothesis $1 \mathrm{~b}$. A higher education level implies a significantly lower propensity to trust unions and the same is true for the socioeconomic status, the two first categories (representing people with a higher status) being those showing a significantly lower confidence ( 5 and 3 per cent lower) in unions in comparison to 'Routine occupations' (the reference category). Moreover, people with migrant origins (born outside of the country), generally holding more precarious positions in the labour market, have a 5 per cent higher likelihood of trusting unions.

In the third model, we include an additional interaction term to test hypothesis 3 . Looking at the significance and magnitude of the interaction coefficients, we see that the effect of political orientation on confidence in unions is more pronounced for people with a high socioeconomic status, lending some support to hypothesis 3 . For example, in comparison to people employed in 'Routine occupations', a 1-point shift to the left in the political 
orientation scale increases the propensity of being confident in unions for people with the highest socioeconomic status by 4 per cent more.

We now direct our attention to the second group of models, where we gradually add country-level contextual determinants to the variables of the first model. Since the individual-level coefficients remain mostly consistent, we will not comment on them. The first contextual variable we introduce in model 4 is a categorical variable representing the country in which the interview has been conducted. The reference country is the United Kingdom since it shows the lowest level of confidence in unions. Since all countries show significant differences in comparison to the United Kingdom, this implies that the individual controls included are not enough to explain the inter-country variability. We thus include additional country-level variables to shed some light on the reasons of this variability.

In model 5, we include two variables representing the economic conditions of a country. We see that the effect of the transformed GDP variable is in line with hypothesis 4 , since it significantly increases the confidence in unions. The unemployment rate, on the contrary, shows no significant impact on the outcome variable. Interestingly, these two variables do not lead to important changes in the coefficients of the country dummies. They hence do not explain the country differences. However, they do lead to a change of the sign of the effects associated with time dummies, showing that economic conditions have an important influence on the time trends we observe.

Including the level of bargaining coordination in model 6, the time dummies and both economic variables become insignificant. Looking at the variable itself, in line with hypothesis 5 , we see that a middle level of coordination is associated with a significantly higher propensity ( 9 per cent) to trust unions in comparison to a situation of low coordination. In other words, the stronger the bargaining power of unions is, the more they are trusted. However, quite surprisingly, a strong level of coordination does not show a significant effect in comparison to the low one. The result might be related to a problem of statistical power since, among the 14 countries we consider; only a couple of them show a strong level of coordination in at least one wave. Furthermore, adding this variable sheds also some light on the inter-country variability. The coefficients of Austria, France, Germany, Italy, Spain and Sweden become insignificant, suggesting that the higher confidence their population has in unions in comparison to the one in the United Kingdom is related to the higher importance unions have as bargaining actors in such national contexts.

In model 7, we include the two variables measuring the level of employment protection for regular and temporary workers, which renders all categories of bargaining coordination to become insignificant. This implies that the force of unions is reflected in legal arrangements to protect workers. The effects of the two types of regulations, in line with hypothesis 5 , are both positive (4 per cent for regular workers and 2 per cent for temporary ones) and highly significant. The more an individual perceives that labour is protected at the legal level, the more confidence has in unions. Additionally, we see that these variables contribute to explaining the variability between countries 
since now only Ireland, Italy, the Netherlands and Norway significantly differ from the United Kingdom. While for Ireland, the Netherlands and Norway this difference is probably explained by the very strong role unions play in these countries, Italy shows an interesting result since its coefficient is now significant, but with a negative sign. This suggests that the advantage Italy has in terms of confidence in unions in comparison to the United Kingdom is so much related to legal aspects that, once these aspects are controlled for, the situation is reversed.

Since economic conditions demonstrated to have an important influence on the time trends (model 5), we finally estimated an additional model analysing the interaction between wave dummies and unemployment rate. In this last model, we see that there is a significant positive interaction effect only between the fourth wave and unemployment rate. This implies that the important increase in the level of confidence in unions in the fourth wave (cf. Figure 1) is at least in part related to an increase in the unemployment rate. Thus, in times of economic crises, a higher unemployment rate triggers a generalized feeling of vulnerability and hence people grant more confidence to unions (hypothesis 1b).

\section{Discussion}

While union density has declined, confidence in unions has experienced an overall growth across Western European countries between 1981 and 2009. Even though it is more pronounced in some national contexts than in others, the increasing trend is observable in almost all countries of our sample, Sweden and Austria being the exception. Unions are considered a relevant and trustworthy social institution by a considerable part of society, and increasingly so through time. This finding contrasts with the both commonly accepted crisis of confidence in institutions and crisis of unionism narratives that suggest a worsening future for the legitimacy of public institutions (Farnsworth 2003; Newton and Norris 2000) and for trade unions more specifically (Avdagic and Baccaro 2016).

Unions are stably considered as a legitimate social institution by traditional supporter strongholds, such as unionized employees, who directly experience the institutional performance of unions, and politically interested left-wing individuals, who support unions' general goals. Moreover, people reward unions with trust if unions show that they 'can' protect and enhance their conditions, essentially pushing for legal employment protection and contributing to the country's economic well-being. However, this support alone does not explain the level and especially the growth of confidence in unions in the last wave. Indeed, much of the confidence is granted to unions by social groups that are particularly vulnerable. Less wealthy individuals, younger people, migrants, retirees, unemployed and housewives, who have more mediated and distant relations with unions, express higher confidence in unions than full-time employees. Individuals having more vulnerable profiles 
hope that unions 'will' take action to alleviate their vulnerability. Moreover, the consideration of a wide set of contextual variables - previously not included or overlooked in the study of confidence in institutions and public opinion about unions (e.g. Givan and Hipp 2012) - allowed understanding that vulnerability counts not only in terms of personal characteristics but also in terms of contextual circumstances. In particular, during the beginning of the unprecedented economic crisis in 2008, the fear of becoming more vulnerable seems to spread in the society and in turn leads people to trust unions more. It is a 'leap of faith' that pushes people hoping that unions 'will $d o$ ' use their 'sword of justice' to make them less defenceless and less exposed to the consequences of economic shocks.

Such findings lead us to consider unions' social legitimacy in a different perspective. Social vulnerability and negative economic conjunctures undermine both confidences towards social institutions (other than unions) and union membership but increase trust in unions. Thus, the crisis of confidence in institutions, does not apply to unions. Moreover, our results show how the crisis of unionism debate is too narrowly based on union density trends from which a crisis of union social legitimacy is supported. People who are in vulnerable social positions or who are fearful to become vulnerable in the presence of major shocks still believe that unions can empower or, at least, protect them. Paradoxically, the feeling of vulnerability decreases the chances of joining a union while it has the opposite impact on the attitudinal component.

Our findings are of relevance for union representation and organizing. In the last decades, unions have experienced difficulties to effectively respond to the need of representation and to provide a collective voice for more vulnerable employees (Fine 2006; Gumbrell-McCormick 2011; Wills 2009). They tried to take action and develop targeted strategies to represent different employee interests (Bercusson and Dickens 1996; Heery 2005), focusing on both internal (towards members) and external (towards non-members and more vulnerable employees) needs. The challenge posited by this paper is to go a step further. Most vulnerable people cannot become members either because their precarious working conditions make the affiliation to a union difficult or because they do not belong to the labour force. Our findings suggest that the concept of union representation should be based on a much broader notion of the role of trade unions, being aimed at including not only non-organized and vulnerable employees (Fitzgerald and Hardy 2010; Heery and Adler 2004) but also vulnerable individuals outside of the labour market, especially in a moment of widespread social feelings of vulnerability. Such a representation and organizing radical turn could allow unions to fully embrace the model of the social movement unionism (e.g. Fairbrother 2008; Turner et al. 2001), a possible opportunity to contrast the strong decline they are experiencing in traditional forms of workplace representation.

It remains to be explained why people who only have indirect or distant relationships with unions express high confidence in unions. This puzzling finding suggests that there might be other channels than union membership 
through which unions are able to reach these individuals. The revitalization process unions initiated in the 1990s led them to step outside of their traditional role of labour market regulators and to defend their role through an important presence in the public arena (Baccaro et al. 2003). Unions are increasingly active in the media and their voice has become louder, especially during periods with economic constraints and crises, political changes affecting vulnerable people (such as welfare reforms) and scandals that may concern them. Media coverage can affect both confidence in institutions (Moy and Pfau 2000), and public opinion about unions (Carreiro 2005; Schmidt 1993). In fact the media can make salient to public opinion unions' institutional goals and success in achieving them but also publicize their failures or scandals, in which unions are directly or indirectly involved (Smith 2012). The mediatization of unions might thus be able to explain time fluctuations in union confidence. Therefore, the union mediatization, in terms of both union presence and how unions are portrayed in the media, might be the missing element of our analyses. Unfortunately, we cannot test this effect since a measure of the level of mediatization of union activities has not yet been constructed to our knowledge.

However, for instance, Sweden, a fortress of coordinated and cooperative employment relations, exhibits the strongest negative trend in terms of confidence towards unions between 1981 and 2008 (almost 10 per cent). While there is no straightforward explanation of this trend, it might be linked to the notable decline of corporatism during the eighties (Lewin 1994). Ever since 1980, there has been a strong increase in strikes and lockouts, accompanied by worsening economic conditions and a rising distrust in the social democratic party, closely associated with the union movement (Lewin 1994: 63-4). Eventually, the Swedish union confederation LO supported the government's proposal to forbid strikes in 1989, which led to 'outraged protest' (Lewin 1994: 76). The consecutive moderate decline in trust after 2000 might be related to a series of mediatised corporate governance scandals in which unions as social partners where involved (Habbard 2008: 20). Likewise, in Austria, the other country representing an exception to the overall positive confidence trend, the news of the involvement of the partly union owned bank BAWAG in a financial scandal in 2005 was only the latest of a series of scandals that might have undermined trust in Austrian unions over time (Kunkel and Pontusson 1998; Traxler and Pernicka 2007). Moreover, one of the highest growths of confidence in unions over time is observed in Ireland, a country with an AngloSaxon employment relations regime. Between 1990 and 2008, the public discourse around tri-partite pacts and the increase of employment protection might have created a socially integrating and motivating environment that highlighted unions' effectiveness (Crouch 2014; Geary 2015; Regan 2010: 256). 


\section{Concluding remarks and future directions}

Although union density and confidence in public institutions are declining, confidence in and thus the legitimacy of unions have overall increased between 1981 and 2008 in Europe. Our findings demonstrate how unions' social legitimacy has not decreased, contrasting both the crisis of confidence in institutions and the crisis of unionism narratives. The legitimacy of unions is based on traditional union strongholds, such as unionized employees and left-wing citizens but interestingly also on precarious and socially vulnerable groups that trust unions' ability to empower them. Factors that constrain individuals in joining unions and that aggravate distrust of public institutions seem to boost confidence in unions.

The main limitations of the paper are related to data constraints. In fact, despite their richness, the data of the EVS do not always provide optimal operationalizations of some of the concepts at the core of our hypothesis. In particular, vulnerability of employed people could have been better explored through the type of their contract (such as permanent, short-term, temporary) and the feeling of precariousness through a question considering the perceived risk of unemployment. Furthermore, the main explanation we use to make sense of the level of confidence of people outside of the labour market, the mediatization of unions' actions, cannot be tested due to the absence of a suitable measure. The development of such a measure constitutes hence a very promising future research path. Nonetheless, the main findings of our study show unequivocally a confidence trend that challenges the traditional crises of confidence and crisis of unionism narratives and gives at least a glimpse of hope for the future of unions in Western Europe. Unions can build on a basis of substantial social support. To take advantage of this trust reservoir, the main challenge for unions remains to develop more comprehensive representation horizons and organizing practices, requiring a radical change not easy to implement.

Last but not least, we have to consider that public opinion is an evolving phenomenon. For instance, Eurobarometer provides data about confidence in unions for 2010. In line with some of our country economic considerations, confidence in unions increases in countries with better economic performances during the crisis (such as Austria, German and Sweden) whereas it decreases in countries more deeply touched by the economic crisis (such as in Spain, Portugal and Ireland). In these countries, after a moment of 'hope' in unions at the beginning of the crisis, people seem to perceive more union limitations in alleviating the crisis. After the shock of these 2008 crisis, it seems that confidence tends to return to precedent societal levels. Ultimately, confidence in unions reflects the enduring legitimacy of trade unions as a social institution, supported in societies even outside union strongholds. 


\section{Acknowledgements}

All three authors contributed equally to the paper. We would like to thank Gregory Jackson and the anonymous reviewers for their helpful comments and suggestions on this paper. Moreover, we would like to thank Bernhard Ebbinghaus and participants of the Crimt conference for their comments on earlier drafts.

\section{Notes}

1. The disparate uses of the trust concept transformed it in a quagmire (Metlay 1999). While it is not our goal to unravel this quagmire, we highlight two relevant aspects of the debate about trust for our research: first, trust towards institutions has been generally referred to as confidence; second, 'trust in institutions' and 'confidence in institutions' have been used interchangeably. Hence, we use 'confidence in institutions' and 'trust in institutions' in the rest of the article as synonyms.

2. Even though the Eurobarometer (EB) survey includes a question about confidence in unions, it covers a much shorter time period (1997-2010) than the EVS. The correlation between the level of confidence in unions as provided by the EVS and EB for the years 2000 and 2008 is high (2000: Pearson's $r=.72$; 2008: Pearson's $r=.73$; both $p<0.05$ ). Moreover, EB slightly overestimates the level of confidence in comparison to the EVS. EVS data thus provides a more conservative measure.

3. While the face-to-face interviews are conducted in the main languages spoken in a country, and therefore potentially underrepresent immigrant populations, less than 1 percent of the contacted persons could not participate because of language issues, according to the 'extended data description' (http://info1.gesis.org/evs/studies/studydescription.asp).

4. These categories of non-working individuals have been merged because the results we get for each individual category are very similar in all our models. It is hence easier to provide comments on a single category.

\section{References}

Angrist, J. D. and Pischke, J.-S. (2009). Mostly Harmless Econometrics: An Empiricist's Companion. Princeton, NJ: Princeton University Press.

Avdagic, S. and Baccaro, L. (2016). 'The future of employment relations in advanced capitalism: inexorable decline?' In A. Wilkinson, G. Wood, and R. Deeg (eds.), The Oxford Handbook of Employment Relations. Oxford: Oxford University Press, pp. 701-25.

Baccaro, L., Hamann, K. and Turner, L. (2003). 'The politics of labour movement revitalization: the need for a revitalized perspective'. European Journal of Industrial Relations, 9 (1): 119-33.

Barber, B. (1983). The Logic and Limits of Trust. New Brunswick, NJ: Rutgers University Press.

Bennett, J. T. and Kaufman, B. E. (eds.) (2007). What Do Unions Do?: A Twenty-Year Perspective. New Brunswick, NJ: Transaction Publishers.

Bercusson, B. and Dickens, L. (1996). Equal Opportunities and Collective Bargaining in Europe: Defining the Issues v. 1. Loughlinstown, Dublin: European Commission. 
Blanchflower, D. and Oswald, A. (2008). 'Is well-being U-shaped over the life cycle?' Social Science \& Medicine, 66 (8): 1733-49.

Böckerman, P. and Uusitalo, R. (2006). 'Erosion of the Ghent System and union membership decline: lessons from Finland'. British Journal of Industrial Relations, 44 (2): 283-303.

Brady, D. (2007). 'Institutional, economic, or solidaristic? Assessing explanations for unionization across affluent democracies'. Work and Occupations, 34 (1): 67-101.

Bronfenbrenner, K. and Hickey, R. (2004). 'Changing to organize'. In R. Milkman and K. Voss (eds.), Rebuilding Labor: Organizing and Organizers in the New Union Movement. Ithaca, NY: Cornell University Press, pp. 17-61.

Brym, R., Bauer, L. B. and McIvor, M. (2013). 'Is industrial unrest reviving in Canada? Strike duration in the early twenty-first century'. Canadian Review of Sociology, 50 (2): 227-38.

Bryson, A., Ebbinghaus, B. and Visser, J. (2011). 'Introduction: causes, consequences and cures of union decline'. European Journal of Industrial Relations, 17 (2): 97-105. - and Gomez, R. (2005). 'Why have workers stopped joining unions? The rise in never-membership in Britain'. British Journal of Industrial Relations, 43 (1): 67-92.

Burgess, J., Connell, J. and Winterton, J. (2013). 'Vulnerable workers, precarious work and the role of trade unions and HRM'. International Journal of Human Resource Management, 24 (22): 4083-93.

Carreiro, J. L. (2005). 'Newspaper coverage of the US labor movement: the case of anti-union firings 1'. Labor Studies Journal, 30 (3): 1-20.

Checchi, D. and Visser, J. (2005). 'Pattern persistence in European trade union density: a longitudinal analysis 1950-1996'. European Sociological Review, 21 (1): 1-21.

—_ and Van De Werfhorst, H. G. (2010). 'Inequality and union membership: the influence of relative earnings and inequality attitudes'. British Journal of Industrial Relations, 48 (1): 84-108.

Colquitt, J. A., Scott, B. A. and LePine, J. A. (2007). 'Trust, trustworthiness, and trust propensity: a meta-analytic test of their unique relationships with risk taking and job performance'. Journal of Applied Psychology, 92 (4): 909-27.

Cregan, C. (2005). 'Can organizing work? An inductive analysis of individual attitudes toward union membership'. Industrial \& Labor Relations Review, 58 (2): 282-304.

Crouch, C. (1985). 'Conditions for trade union wage restraint'. In L. N. Lindberg and C. S. Maier (eds.), The Politics of Inflation and Economic Stagnation. Washington, DC: Brookings Institution, pp. 105-39.

(2014). 'The neo-liberal turn and the implications for labour'. In A. Wilkinson, G. Wood, and R. Deeg (eds.), The Oxford Handbook of Employment Relations: Comparative Employment Systems. Oxford: Oxford University Press, pp. 589-614.

Culpepper, P. D. and Regan, A. (2014). 'Why don't governments need trade unions anymore? The death of social pacts in Ireland and Italy'. Socio-Economic Review, 12 (4): 723-45.

Cvetkovich, G. and Earle, T. (1995). Social Trust: Toward a Cosmopolitan Society. Westport, CT: Praeger.

D'Art, D. and Turner, T. (2008). 'Workers and the demand for trade unions in Europe: still a relevant social force?' Economic and Industrial Democracy, 29 (2): 165-91.

Ebbinghaus, B., Göbel, C. and Koos, S. (2011). 'Social capital, "Ghent" and workplace contexts matter: comparing union membership in Europe'. European Journal of Industrial Relations, 17 (2): 107-24.

- and Visser, J. (1999). 'When institutions matter: union growth and decline in Western Europe, 1950-1995'. European Sociological Review, 15 (2): 135-58. 
Fairbrother, P. (2008). 'Social movement unionism or trade unions as social movements'. Employee Responsibilities and Rights Journal, 20 (3): 213-20.

Farnsworth, S. J. (2003). Political Support in a Frustrated America. Westport, CT: Praeger.

Fine, J. (2006). Worker Centers: Organizing Communities at the Edge of the Dream. Ithaca, NY: Cornell University Press.

Fitzgerald, I. and Hardy, J. (2010). "Thinking outside the box"? Trade union organizing strategies and polish migrant workers in the United Kingdom'. British Journal of Industrial Relations, 48 (1): 131-50.

Flanders, A. (1975). Management and Unions: Theory and Reform of Industrial Relations. London: Faber \& Faber.

Frangi, L. and Barisione, M. (2015). “Are you a union member?” Determinants and trends of subjective union membership in Italian society (1972-2013)'. Transfer: European Review of Labour and Research, 21 (4): 451-69.

Freeman, R. (2007). Do Workers Still Want Unions? Yes More than Ever! Washington, DC: Economic Policy Institute, pp. 1-13.

— Boxall, P. and Haynes, P. (2007). What Workers Say: Employee Voice in the AngloAmerican Workplace. Ithaca, NY: Cornell University Press.

and Rogers, J. (2006). What Workers Want. Ithaca, NY: ILR Press.

Gabel, M. and Hix, S. (2002). 'Defining the EU political space: an empirical study of the European elections manifestos, 1979-1999'. Comparative Political Studies, 35 (8): 934-64.

Geary, J. (2015). 'Economic crisis, austerity and trade union responses: the Irish case in comparative perspective'. European Journal of Industrial Relations, 22 (2): 131-47.

Givan, R. K. and Hipp, L. (2012). 'Public perceptions of union efficacy: a twenty-four country study'. Labor Studies Journal, 37 (1): 7-32.

Goslinga, S. and Sverke, M. (2003). 'Atypical work and trade union membership: union attitudes and union turnover among traditional vs atypically employed union members'. Economic and Industrial Democracy, 24 (2): 290-312.

Greenfield, P. M. (2009). 'Linking social change and developmental change: shifting pathways of human development'. Developmental Psychology, 45 (2): 401-18.

Guiso, L., Sapienza, P. and Zingales, L. (2006). 'Does culture affect economic outcomes?' Journal of Economic Perspectives, 20 (2): 23-48.

Gumbrell-McCormick, R. (2011). 'European trade unions and “atypical” workers'. Industrial Relations Journal, 42 (3): 293-310.

- and Hyman, R. (2013). Trade Unions in Western Europe: Hard Times, Hard Choices. Oxford: Oxford University Press.

Habbard, P. (2008). Corporate Governance in Sweden-An International Trade Union Perspective. Paris: Hans Böckler Foundation in partnership with the Global Union Research Network.

Häusermann, S. and Schwander, H. (2012). 'Varieties of dualization? Labor market segmentation and insider-outsider divides across regimes'. In P. Emmenegger, S. Häusermann, B. Palier, and M. Seeleib-Kaiser (eds.), The Age of Dualization: The Changing Face of Inequality in Deindustrializing Societies. New York: Oxford University Press, pp. 27-51.

Heery, E. (2005). 'Sources of change in trade unions'. Work, Employment \& Society, 19 (1): 91-106.

— and Adler, L. (2004). 'Organizing the unorganized'. In C. Frege and J. Kelly (eds.), Varieties of Unionism: Strategies for Union Revitalization in a Globalizing Economy. New York: Oxford University Press. 
Heshizer, B. (1985). 'Unions and public opinion: why the declining relationship?' Labour Studies Journal, 9 (3): 254-70.

Hyman, R. (2001). Understanding European Trade Unionism: Between Market, Class and Society. New York: Sage.

— (2002). 'The future of unions'. Just Labour, 1 (1): 7-15.

and Gumbrell-McCormick, R. (2010). 'Trade unions, politics and parties: is a new configuration possible?' Transfer: European Review of Labour and Research, 16 (3): 315-31.

Kenworthy, L. (2001). 'Wage-setting measures: a survey and assessment'. World Politics, 54 (1): 57-98.

King, D. C. and Karabell, Z. (2003). The Generation of Trust: Public Confidence in the US Military since Vietnam. Washington, DC: American Enterprise Institute.

Kirmanoğlu, H. and Başlevent, C. (2012). 'Using basic personal values to test theories of union membership'. Socio-Economic Review, 10 (4): 683-703.

Knack, S. and Keefer, P. (1997). 'Does social capital have an economic payoff? A crosscountry investigation'. Quarterly Journal of Economics, 112 (4): 1251-88.

Kochan, T. A. (1979). 'How American workers view labor unions'. Monthly Labor Review, 102 (4): 23-31.

Kunkel, C. and Pontusson, J. (1998). 'Corporatism versus social democracy: divergent fortunes of the Austrian and Swedish labour movements'. West European Politics, $21(2): 1-31$.

Lee, C.-S. (2005). 'International migration, deindustrialization and union decline in 16 affluent OECD countries, 1962-1997'. Social Forces, 84 (1): 71-88.

Lewin, L. (1994). 'The rise and decline of corporatism: the case of Sweden'. European Journal of Political Research, 26 (1): 59-79.

Lipset, S. M. and Meltz, N. M. (2004). The Paradox of American Unionism: Why Americans Like Unions More Than Canadians Do, But Join Much Less. Ithaca, NY: Cornell University Press.

— and Schneider, W. (1987). 'The confidence gap during the Reagan years, 19811987’. Political Science Quarterly, 102 (1): 1-23.

Listhaug, O. and Wiberg, M. (1995). 'Confidence in political and private institutions'. In H.-D. Klingemann and D. Fuchs (eds.), Citizens and the State. Oxford: Oxford University Press, pp. 298-322.

Luhmann, N. (1988). 'Familiarity, confidence, trust: problems and perspectives'. In D. Gambetta (ed.), Trust: Making and Breaking Cooperative Relations. Oxford: WileyBasil Blackwell, pp. 94-107.

Mayer, R. C., Davis, J. H. and Schoorman, F. D. (1995). 'An integrative model of organizational trust'. Academy of Management Review, 20 (3): 709-34.

McGovern, P. (2007). 'Immigration, labour markets and employment relations: problems and prospects'. British Journal of Industrial Relations, 45 (2): 217-35.

Metlay, D. (1999). 'Institutional trust and confidence: a journey into a conceptual quagmire'. In G. Cvetkovich and R. Löfstedt (eds.), Social Trust and the Management of Risk. Abingdon, Oxon: Earthscan, pp. 100-16.

Misztal, B. (2013). Trust in Modern Societies: The Search for the Bases of Social Order. Cambridge: Polity.

Mood, C. (2010). 'Logistic regression: why we cannot do what we think we can do, and what we can do about it'. European Sociological Review, 26 (1): 67-82.

Moy, P. and Pfau, M. (2000). With Malice Toward All?: The Media and Public Confidence in Democratic Institutions. Westport, CT: Praeger. 
Newton, K. and Norris, P. (2000). 'Confidence in public institutions'. In S. J. Pharr and R. D. Putnam (eds.), Disaffected Democracies: What's Troubling the Trilateral Countries?. Princeton, NJ: Princeton University Press, pp. 52-73.

Price, V. and Romantan, A. (2004). 'Confidence in institutions before, during, and after "Indecision 2000"”. The Journal of Politics, 66 (3): 939-56.

Regan, A. (2010). 'Does discourse matter in the formation and consolidation of social pacts? Social partnership and labor market policy in Ireland'. Critical Policy Studies, 4 (3): $250-77$.

Rosenfeld, J. (2014). What Unions No Longer Do. Cambridge, MA: Harvard University Press.

Rothstein, B. and Stolle, D. (2008). 'The state and social capital: an institutional theory of generalized trust'. Comparative Politics, 40 (4): 441-59.

Sapsford, R. and Abbott, P. (2006). 'Trust, confidence and social environment in postcommunist societies'. Communist and Post-Communist Studies, 39 (1): 59-71.

Scheuer, S. (2011). 'Union membership variation in Europe: a ten-country comparative analysis'. European Journal of Industrial Relations, 17 (1): 57-73.

Schmidt, D. E. (1993). 'Public opinion and media coverage of labor unions'. Journal of Labor Research, 14 (2): 151-64.

Schmitt, J. and Mitukiewicz, A. (2012). 'Politics matter: changes in unionisation rates in rich countries, 1960-2010'. Industrial Relations Journal, 43 (3): 260-80.

Schmitter, P. C. and Streeck, W. (1981). The organization of business interests: a research design to study the associative action of business in the advanced industrial societies of Western Europe. Berlin: Wissenschaftszentrum Berlin.

Schnabel, C. (2013). 'Union membership and density: some (not so) stylized facts and challenges'. European Journal of Industrial Relations, 19 (3): 255-72.

Schwadel, P. and Stout, M. (2012). 'Age, period and cohort effects on social capital'. Social Forces, 91 (1): 233-52.

Simmel, G. (1950). The Sociology of Georg Simmel. New York: Free Press.

Smith, T. W. (2012). 'Trends in confidence in institutions, 1973-2006'. In P. V. Marsden (ed.), Social Trends in American Life. Princeton, NJ: Princeton University Press, pp. 177-211.

Snape, E. and Redman, T. (2004). 'Exchange or covenant? The nature of the memberunion relationship'. Industrial Relations: A Journal of Economy and Society, 43 (4): 855-73.

Streeck, W. and Hassel, A. (2003). 'Trade unions as political actors'. In J. T. Addison and C. Schnabel (eds.), International Handbook of Trade Unions. Cheltenham: Edward Elgar, pp. 335-65.

Sullivan, R. (2010). 'Labour market or labour movement? The union density bias as barrier to labour renewal'. Work, Employment \& Society, 24 (1): 145-56.

Traxler, F. and Pernicka, S. (2007). 'The state of unions: Austria'. Journal of Labor Research, 28 (2): 207-32.

Turner, L., Katz, H. C. and Hurd, R. W. (eds.) (2001). Rekindling the Movement: Labor's Quest for Relevance in the 21st Century. Ithaca, NY: ILR Press.

Turner, T. and D'Art, D. (2012). 'Public perceptions of trade unions in countries of the European Union: a causal analysis'. Labor Studies Journal, 37 (1): 33-55.

- _ and O'Sullivan, M. (2008). 'Union availability, union membership and immigrant workers: an empirical investigation of the Irish case'. Employee Relations, 30 (5): 479-93. 
Twenge, J. M., Campbell, W. K. and Carter, N. T. (2014). 'Declines in trust in others and confidence in institutions among American adults and late adolescents, 19722012'. Psychological Science, 25 (10): 1914-23.

Uslaner, E. M. (2003). 'Trust, democracy and governance: can government policies influence generalized trust?' In M. Hooghe and D. Stolle (eds.), Generating Social Capital. New York: Palgrave Macmillan, pp. 171-90.

Wallerstein, M. and Western, B. (2000). 'Unions in decline? What has changed and why'. Annual Review of Political Science, 3 (1): 355-77.

Wang, L. and Gordon, P. (2011). 'Trust and institutions: a multilevel analysis'. The Journal of Socio-Economics, 40 (5): 583-93.

Weber, M. (1958). From Max Weber: Essays in Sociology. In H. H. Gerth and C. W. Mills (eds.), Oxford: Oxford University Press.

Western, B. (1994). 'Institutional mechanisms for unionization in sixteen OECD countries: an analysis of social survey data'. Social Forces, 73 (2): 497-519.

Wills, J. (2009). 'Subcontracted employment and its challenge to labor'. Labor Studies Journal, 34 (4): 441-60.

Wooldridge, J. M. (2010). Econometric Analysis of Cross Section and Panel Data. Cambridge, MA: MIT Press.

Yamagishi, T. (2003). 'Cross-societal experimentation on trust: a comparison of the United States and Japan'. In E. Ostrom and J. Walker (eds.), Trust and Reciprocity: Interdisciplinary Lessons from Experimental Research. New York: Russell Sage Foundation, pp. 352-70.

Zak, P. J. and Knack, S. (2001). 'Trust and growth'. The Economic Journal, 111 (470): 295-321. 
Appendix

TABLE A1

Descriptive Statistics for Individual-Level Independent Variables (Pooled Sample)

\begin{tabular}{llll}
\hline & Range & Mean & Standard deviation \\
\hline Wave & & & \\
1 & $0-1$ & 0.17 & 0.38 \\
2 & $0-1$ & 0.30 & 0.46 \\
3 & $0-1$ & 0.23 & 0.42 \\
4 & $0-1$ & 0.29 & 0.45 \\
Union membership & $0-1$ & 0.21 & 0.41 \\
Female & $0-1$ & 0.49 & 0.50 \\
Age & & & \\
$0-30$ & $0-1$ & 0.24 & 0.43 \\
31-50 & $0-1$ & 0.38 & 0.49 \\
51 or more & $0-1$ & 0.38 & 0.49 \\
Household income & & & 0.46 \\
Low & $0-1$ & 0.30 & 0.48 \\
Medium & $0-1$ & 0.37 & 0.47 \\
High & $0-1$ & 0.33 & 0.50 \\
Employment status & & & 0.27 \\
Employee full-time & $0-1$ & 0.44 & 0.24 \\
Employee part time & $0-1$ & 0.08 & 0.49 \\
Self-employed & $0-1$ & 0.06 & 2.02 \\
$\quad$ Non-working & $0-1$ & 0.42 & 0.94 \\
Political orientation & $1-10$ & 5.27 & 0.95 \\
Political interest & $0-3$ & 1.49 & \\
Political activism & $0-3$ & 0.97 &
\end{tabular}

Note: $N=42,326$.

Source: EVS (1981-2009), own estimations. 
TABLE A2

Descriptive Statistics for Individual-Level Independent Variables (2008-2009 Wave)

\begin{tabular}{|c|c|c|c|}
\hline & Range & Mean & Standard deviation \\
\hline Wave 4 & $0-1$ & 1 & 0 \\
\hline Union membership & $0-1$ & 0.20 & 0.40 \\
\hline Female & $0-1$ & 0.50 & 0.50 \\
\hline \multicolumn{4}{|l|}{ Age } \\
\hline $0-30$ & $0-1$ & 0.16 & 0.37 \\
\hline $31-50$ & $0-1$ & 0.38 & 0.48 \\
\hline 51 or more & $0-1$ & 0.46 & 0.50 \\
\hline \multicolumn{4}{|l|}{ Household income } \\
\hline Low & $0-1$ & 0.31 & 0.46 \\
\hline Medium & $0-1$ & 0.37 & 0.48 \\
\hline High & $0-1$ & 0.32 & 0.47 \\
\hline \multicolumn{4}{|l|}{ Employment status } \\
\hline Employee full-time & $0-1$ & 0.45 & 0.50 \\
\hline Employee part time & $0-1$ & 0.08 & 0.28 \\
\hline Self-employed & $0-1$ & 0.06 & 0.23 \\
\hline Non-working & $0-1$ & 0.41 & 0.49 \\
\hline Political orientation & $1-10$ & 5.18 & 2.04 \\
\hline Political interest & $0-3$ & 1.58 & 0.92 \\
\hline Political activism & $0-3$ & 1.09 & 0.96 \\
\hline \multicolumn{4}{|l|}{ Education level } \\
\hline Lower & $0-1$ & 0.28 & 0.45 \\
\hline Middle & $0-1$ & 0.61 & 0.49 \\
\hline Upper & $0-1$ & 0.11 & 0.31 \\
\hline \multicolumn{4}{|l|}{ Social class } \\
\hline Large employers & $0-1$ & 0.13 & 0.34 \\
\hline Lower managers & $0-1$ & 0.24 & 0.43 \\
\hline Intermediate occupations & $0-1$ & 0.12 & 0.33 \\
\hline Small employers & $0-1$ & 0.06 & 0.23 \\
\hline Small employers agric. & $0-1$ & 0.01 & 0.11 \\
\hline Lower supervisors & $0-1$ & 0.09 & 0.28 \\
\hline Lower sales and service & $0-1$ & 0.12 & 0.32 \\
\hline Lower technical occupations & $0-1$ & 0.09 & 0.28 \\
\hline Routine occupations & $0-1$ & 0.15 & 0.36 \\
\hline Born outside of the country & $0-1$ & 0.07 & 0.25 \\
\hline
\end{tabular}

Note: $N=11,421$.

Source: EVS (2008-2009), own estimations. 
TABLE A3

Descriptive Statistics for Contextual-Level Independent Variables

\begin{tabular}{lccc}
\hline & Range & Mean & Standard deviation \\
\hline Contextual-level variables & & & \\
Country & & & \\
$\quad$ Austria & $0-1$ & 0.07 & 0.25 \\
Belgium & $0-1$ & 0.09 & 0.29 \\
Denmark & $0-1$ & 0.07 & 0.26 \\
Finland & $0-1$ & 0.04 & 0.20 \\
France & $0-1$ & 0.08 & 0.28 \\
Germany & $0-1$ & 0.14 & 0.35 \\
Ireland & $0-1$ & 0.05 & 0.21 \\
Italy & $0-1$ & 0.08 & 0.28 \\
Netherlands & $0-1$ & 0.08 & 0.27 \\
Norway & $0-1$ & 0.06 & 0.24 \\
Portugal & $0-1$ & 0.04 & 0.20 \\
Spain & $0-1$ & 0.09 & 0.28 \\
Sweden & $0-1$ & 0.03 & 0.17 \\
United Kingdom & $0-1$ & 0.07 & 0.25 \\
ln(GDP per capita/1,000) & $1.69-4.57$ & 3.16 & 0.63 \\
Unemployment rate & $2.6-16.4$ & 7.81 & 3.63 \\
Coordination of wage bargaining & & & \\
$\quad$ Weak & $0-1$ & 0.08 & 0.27 \\
Moderate & $0-1$ & 0.34 & 0.47 \\
Strong & $0-1$ & 0.59 & 0.49 \\
Empl. prot. regular & $1.09-4.83$ & 2.49 & 0.73 \\
Empl. prot. temporary & $0.25-5.25$ & 2.41 & 1.39 \\
\hline
\end{tabular}

